\title{
The use of adjuvants to improve uptake of phosphorous acid applied to Pinus radiata needles for control of foliar Phytophthora diseases
}

\author{
Carol Rolando ${ }^{*}$, Robyn Gaskin ${ }^{2}$, David Horgan², Nari Williams ${ }^{1}$ and Martin K-F Bader ${ }^{1}$
}

\begin{abstract}
Background: Phosphorous acid is being investigated as a fungicide for the management of a needle disease caused by Phytophthora pluvialis in Pinus radiata in New Zealand. However, little is known about the penetration characteristics of this fungicide into Pinus radiata foliage. This study was undertaken to determine: i) the penetration characteristics of a commercial phosphorous acid formulation, applied at $3 \mathrm{~kg} \mathrm{ha}^{-1}$ and $12 \mathrm{~kg} \mathrm{ha}^{-1}$ in $100 \mathrm{~L}$ water, into Pinus radiata foliage and, ii) the effect of four commercially available adjuvants on phosphorous acid uptake into Pinus radiata foliage. Efficacy of the best treatment was tested in vitro with two Phytophthora species, Phytophthora kernoviae and P. pluvialis.
\end{abstract}

Methods: Foliar uptake of orthophosphoric acid radio-labelled with $\left[{ }^{32} \mathrm{P}\right]$ was used to determine penetration characteristics of phosphorous acid as affected by the adjuvants tested. Needles collected from potted Pinus radiata plants sprayed with the best performing treatment were used in a detached needle assay, where treated needles were exposed to the zoospores of the Phytophthora species being tested.

Results: Uptake of the phosphorous acid formulation into Pinus radiata needles applied without adjuvants was low (3.9-6.6\%) at both concentrations tested. An alcohol ethoxylate adjuvant (applied at 0.2\%) and two organosilicone adjuvants (applied at $0.2 \%$ ) were found to significantly increase uptake of the fungicide over that applied alone or in combination with pinolene (applied at 0.35\%). Highest uptake of phosphorous acid into Pinus radiata foliage (51.6\%) occurred over a period of 72 hours when the phosphorous acid was applied at the equivalent of $12 \mathrm{~kg} \mathrm{ha}^{-1}$ with an organosilicone blend adjuvant at $0.2 \%$. A significant reduction in lesion length on infected needles was found relative to the control when the two phosphorous acid treatments were applied with $0.2 \%$ organosilicone blend adjuvant. However, there were no significant differences in lesion length between the two treatments.

Conclusions: These results show that an organosilicone adjuvant significantly enhances uptake of phosphorous acid into Pinus radiata needles and may increase its efficacy against Phytophthora species.

Keywords: Alcohol ethoxylate; Organosilicone; Pinolene; Forest disease management; Penetration

\section{Background}

A new needle disease was reported in Pinus radiata D. Don stands on the east coast of New Zealand during routine forest surveillance in late April 2008. Observations of the symptoms, their development and the apparent spread of the disease, known locally as red needle cast, all gave a strong indication of a likely biotic cause,

\footnotetext{
* Correspondence: carol.rolando@scionresearch.com

${ }^{1}$ Scion, 49 Sala Street, Fenton Park, Private Bag 3020, Rotorua 3046,

New Zealand

Full list of author information is available at the end of the article
}

which led to further investigations. Isolations made from symptomatic needles yielded an undescribed species of Phytophthora as the likely causal pathogen (Dick et al. 2014). The causal pathogen has recently been described as Phytophthora pluvialis which is considered to be endemic to Oregon, USA (Reeser et al. 2013). Subsequently, a second species Phytophthora kernoviae Brasier, Beales \& Kirk, was also recovered from needles, though at a consistently lower rate (Dick et al. 2014). Concurrent to epidemiological work for red needle cast, a range of trials were initiated to investigate possible fungicides that could be

\section{实}


effective for management of red needle cast on Pinus radiata in New Zealand. Phosphorous acid was chosen as a key fungicide for further research on potential red needle cast management since this active ingredient (in the form of phosphorous acid) is used widely in agriculture and horticulture for control of Phytophthora species (Lobato et al. 2011; Rebollar-Alviter et al. 2007; Shearer and Crane 2009).

Phosphorous acid fungicides, applied either preinfection or for protectant activity, are the only known ambi-mobile fungicides capable of moving upward and downward in plants (Cohen and Coffey 1986). Phosphorous acid exhibits a complex mode of action, acting both directly on the pathogen and also indirectly by stimulating host defence responses to ultimately inhibit pathogen growth (Tomlin 2006). The fungicide can persist in host plants for several months post application, however persistence is host dependent (Tynan et al. 2001). When treated, most plants exhibit phytotoxic effects above a (species dependent) threshold concentration, with field treated plants more sensitive to phytotoxic effects than those treated in a glasshouse (Hardy et al. 2001). Kanaskie et al. (2011) showed the potential for phosphorous acid to control outbreaks of sudden oak death, caused by Phytophthora ramorum S. Werres, A.W.A.M. de Cock \& W.A. Man, in Notholithocarpus densiflorus (Hook. \& Arn.) Manos, Cannon \& S.H. Oh (south-western Oregon tanoak). Besides the work described by Kanaskie et al. (2011), there are few reports describing the use of phosphorous acid to control Phytophthora spp. associated foliar diseases in mature trees. This is likely because there are few tree-infecting aerial Phytophthora spp. currently known and those which are known (such as $P$. ramorum, P. kernoviae, P. pinifolia and P. pluvialis) have been relatively recently observed. Graham (2011) suggested options for using phosphorous acid to control Phytophthora species in forest trees based on work done on citrus orchards. Phosphorous acid has been successfully used to control Phytophthora root rot in Pinus radiata nurseries (Reglinski et al. 2009). However, the results of this study cannot readily be extrapolated to airborne Phytophthora pathogens infecting mature trees.

Maximising uptake of pesticides is important to optimise efficacy and cost-effectiveness of any chemical control strategy. However, little is known about the penetration characteristics of phosphorous acid into Pinus radiata foliage. Agrochemical adjuvants are commonly used to improve efficacy of systemic pesticides by improving spray deposition and retention on the target species and/or by increasing the penetration of the pesticides into the plant (Zabkiewicz 2000).

This study was undertaken to determine: i) the penetration characteristics of a commercial phosphorous acid formulation into Pinus radiata foliage and, ii) the effect of commercially available adjuvants on phosphorous acid uptake into Pinus radiata foliage. Efficacy of the best treatment was subsequently tested in an in-vitro bioassay conducted with the pathogens, Phytophthora kernoviae and P. pluvialis. Selection was based on a combination of adjuvant chemistry, their mode of action, and current relative cost. Four adjuvants, representing three classes of adjuvant, were selected for testing: i) a low-cost pinolene that is used as a wetter, sticker and rainproofer, ii) a moderately priced non-ionic surfactant typically used to aid wetting, sticking and penetration of fungicides, and iii) two relatively expensive organosilicones that are known to improve retention and coverage of sprays, and are often utilised to increase uptake of systemic pesticides into plants.

\section{Methods}

Three clones (referred to as A, B and C) of grafted Pinus radiata, hereafter referred to as the potted plants, known to be susceptible to the pathogens Phytophthora kernoviae and P. pluvialis, were used in this investigation. The potted plants, supplied from the Radiata Pine Breeding Company Ltd. (Rotorua, New Zealand), were obtained in mid-autumn from the Scion nursery (Rotorua, New Zealand) and were equilibrated for two weeks in a controlled environment cabinet $\left(20 / 15^{\circ} \mathrm{C}, 70 \%\right.$ relative humidity, $12 \mathrm{~h}$ photoperiod, $500 \mu \mathrm{mol} \mathrm{m}{ }^{-2} \mathrm{sec}^{-1}$ light) prior to treatment application. All treatments were applied to one-year-old needles located on the main leader of the potted plants. There were three potted plants of each clone for each treatment, such that all treatments were replicated three times, with three experimental units per clone (three clones $x$ three potted plants of each clone).

A preliminary experiment was undertaken to gauge the uptake of phosphorous acid into Pinus radiata needles without the use of an adjuvant. As there is no label rate for aerial application of phosphorous acid to mature Pinus radiata plantations in New Zealand, the rates used were obtained from aerial application rates used in Western Australia, for Lambertia inermis var. inermis and Banksia grandis, and North America for N. densiflorus (Kanaskie et al. 2011; Shearer and Crane 2009). Phosphorous acid (Agrifos ${ }^{\oplus} 600$, Key Industries; $600 \mathrm{~g} \mathrm{~L}^{-1}$ phosphorous acid) was applied in $100 \mathrm{~L} \mathrm{ha}^{-1}$ of water at two rates $\left(3 \mathrm{~kg} \mathrm{ha}^{-1}\right.$ and $\left.12 \mathrm{~kg} \mathrm{ha}^{-1}\right)$, Treatments $1 \& 2$, Table 1. Based on the results of this initial test, it was decided to use the highest application rate of phosphorous acid in further experiments to increase the likelihood of active ingredient being absorbed by the foliage.

\section{Experiment 1: Effect of four adjuvants on uptake of phosphorous acid Description of adjuvants}

The adjuvants tested were i) a pinolene (Nu-Film-17 ${ }^{\circ}$, Key Industries Ltd, Auckland), ii) a linear alcohol 


\begin{tabular}{|c|c|c|c|c|c|c|}
\hline Treatment no & $\begin{array}{l}\text { Rate of } \\
\text { active }\left(\mathrm{kg} \mathrm{ha}^{-1}\right)\end{array}$ & Adjuvant & $\begin{array}{l}\text { Adjuvant } \\
\text { concentration }\end{array}$ & {$\left[{ }^{32} \mathrm{P}\right]$ uptake $(\%)$} & $\begin{array}{l}{\left[{ }^{32} \mathrm{P}\right] \text { uptake }} \\
\text { dose }^{*}\left(\mathrm{~kg} \mathrm{ha}^{-1}\right)\end{array}$ & $\begin{array}{l}\text { Spread area } \\
\text { of droplets }\left(\mathrm{mm}^{2}\right)\end{array}$ \\
\hline 1 & 3 & None & - & $6.6 \mathrm{~cd}$ & 0.20 & $0.8 \mathrm{~h}$ \\
\hline 2 & 12 & None & - & $3.9 \mathrm{~d}$ & 0.47 & $1.0 \mathrm{~g}$ \\
\hline 3 & 12 & Pinolene & 0.35 & $6.8 \mathrm{~cd}$ & 0.82 & $1.2 \mathrm{f}$ \\
\hline 4 & 12 & Alcohol ethoxylate & 0.05 & $7.7 \mathrm{~cd}$ & 0.92 & $1.5 \mathrm{e}$ \\
\hline 5 & 12 & Alcohol ethoxylate & 0.10 & $18.6 \mathrm{~b}$ & 2.23 & $1.7 \mathrm{~d}$ \\
\hline 6 & 12 & Alcohol ethoxylate & 0.20 & $14.2 \mathrm{bc}$ & 1.70 & $2.0 \mathrm{C}$ \\
\hline 7 & 12 & Organosilicone penetrant & 0.20 & $20.1 \mathrm{~b}$ & 2.41 & $2.3 \mathrm{~b}$ \\
\hline 8 & 12 & Organosilicone blend & 0.20 & 36.9 a & 4.43 & $2.7 \mathrm{a}$ \\
\hline
\end{tabular}

Means within columns sharing common postscripts are not significantly different. *Nominal dose calculated as (phosphorous acid rate $\mathrm{x} \%$ _uptake).

ethoxylate (950 g L ${ }^{-1}$, Actiwett ${ }^{\circ}$, Etec Crop Solutions Ltd, Auckland), iii) a $\mathrm{pH}$-stable organosilicone polymer with super-penetrant activity (Gaskin et al. 2012) containing alcohol ethoxylate and polyalkylene compounds (DuWett ${ }^{\circ}$ Stainless, Etec Crop Solutions Ltd, Auckland) and iv) an organosilicone-blend containing siloxane polyalkeneoxide copolymers (Du-Wett ${ }^{\circ}$, Etec Crop Solutions Ltd, Auckland) designed for use as an horticultural superspreader (AgriMedia Ltd 2013). All adjuvants used in the trial were tested within manufacturer's recommended rates or at rates known to be effective for penetration into horticultural and agricultural crops.

\section{Determination of treatment penetration}

The penetration characteristics of phosphorous acid were tested for up to $24 \mathrm{~h}$ after treatment (HAT). Phosphorous acid was applied as Agrifos $^{\circ} 600$, at the equivalent of $12 \mathrm{~kg} \mathrm{ha}^{-1}$ in $100 \mathrm{~L} \mathrm{ha}^{-1}$ water in combination with the four commercially available adjuvants described in 2.1.1. Details of the adjuvant concentrations (Treatments 3-8) are given in Table 1.

Orthophosphoric acid radio-labelled with $\left[{ }^{32} \mathrm{P}\right]$ (ARC, Inc., USA) was added to freshly prepared treatment solutions in deionised water 30 minutes prior to use to enable the radiaoactive chemical to equilibrate with the mono-and di-potassium salts present in the commercial phosphorous acid formulation. The $\left[{ }^{32} \mathrm{P}\right]$ phosphoric acid comprised $<1 \%$ mass of the total phosphorous acid in solution at all times. Droplets $(10 \times 0.24 \mu \mathrm{L})$ of the radiolabelled treatment solution were applied using a microsyringe to the central region of a single needle per fascicle such that they simulated a $100 \mathrm{~L} \mathrm{ha}^{-1}$ spray application volume (i.e. $1 \mu \mathrm{L} \mathrm{cm}^{-2}$ ). Treated fascicles were pretagged with coloured electrical wire for identification.

The quantity of radiolabelled phosphorous acid applied to each needle in each treatment was determined by dispensing droplets, as applied to plants, directly into scintillation vials (3 replicates). Following treatment application, needle fascicles were harvested at 24 HAT (Table 1). The entire fascicle, including the treated leaf surface, was washed with a mixture of water and ethanol $(1: 1 \mathrm{v} / \mathrm{v} ; 2 \times 4 \mathrm{~mL})$ to recover any unabsorbed phosphorous acid. Prior audits determined that such wash-offs could recover $>95 \%$ of applied phosphorous acid solutions from foliage surfaces at dry-down. Foliage in Treatment \#3 (Table 1) was given an additional wash with $50 \%$ aqueous acetone to ensure all phosphorous acid remaining on the surface was recovered. This extra wash was carried out because of the low solubility of the pinolene adjuvant in aqueous solution.

Scintillant solution (13 mL ACS; Amersham Biosciences, Australia) was added to the washings and radioactivity was quantified by liquid scintillation counting (Packard Tricarb 2100 TR). Foliar uptake was defined as the radioactivity not recovered from washing the treated needles and was calculated as a percentage of the applied dose.

\section{Determination of droplet spread}

In a separate test, all treatment solutions (1-8; Table 1) were prepared as for the penetration experiment but with the addition of a water-soluble fluorescent dye, (Blankophore P, Bayer) at a concentration of $0.5 \% \mathrm{w} / \mathrm{v}$ immediately prior to droplet application. Twelve droplets $(0.24 \mu \mathrm{L})$ of each solution were applied to each of three needles on each potted plant (and different clones). Droplets were left to spread for 10 minutes. Needles were then illuminated with ultra-violet light and photographed. The area of droplet spread in each case was determined using image analysis software $\left(\mathrm{V}++^{\mathrm{mm}}\right.$, Digital Optics Ltd).

\section{Experiment 2: Optimising uptake of phosphorous acid}

The most promising adjuvant identified in the first experiment was the organosilicone-blend superspreader $\left(\mathrm{Du}-\mathrm{Wett}{ }^{\circ}\right)$. The second experiment examined the effect 


\begin{tabular}{|c|c|c|c|c|}
\hline $\begin{array}{l}\text { Treatment } \\
\text { no }\end{array}$ & $\begin{array}{l}\text { Adjuvant } \\
\text { concentration (\%) }\end{array}$ & $\begin{array}{l}\text { Harvest } \\
\text { time HAT }\end{array}$ & $\begin{array}{l}{\left[{ }^{32} \mathrm{P}\right]} \\
\text { uptake (\%) }\end{array}$ & $\begin{array}{l}\left.{ }^{32} \mathrm{P}\right] \text { uptake } \\
\text { dose* }^{*}\left(\mathrm{~kg} \mathrm{ha}^{-1}\right)\end{array}$ \\
\hline $2 R^{\#}$ & none & 24 & $3.5 d$ & 0.42 \\
\hline $8 \mathrm{R}^{\#}$ & 0.20 & 24 & $43.6 \mathrm{abc}$ & 5.23 \\
\hline 9 & 0.05 & 24 & $31.8 \mathrm{c}$ & 3.82 \\
\hline 10 & 0.10 & 24 & 33.6 bc & 4.03 \\
\hline 11 & 0.10 & 72 & $47.3 \mathrm{ab}$ & 5.68 \\
\hline 12 & 0.20 & 72 & $51.6 \mathrm{a}$ & 6.19 \\
\hline
\end{tabular}

Phosphorous acid was applied at the equivalent of $12 \mathrm{~kg} \mathrm{ha}^{-1}$ in all treatments. Means sharing common postscripts are not significantly different. "The postscript $\mathrm{R}$ indicates a repeat treatment.

*Nominal dose calculated as (phosphorous acid rate $\mathrm{x} \%$ _uptake).

of a wider range of application rates of this adjuvant on the uptake of phosphorous acid over a period of 24 to $72 \mathrm{~h}$.

Phosphorous acid containing $\left[{ }^{32} \mathrm{P}\right]$ was applied at the equivalent rate $12 \mathrm{~kg} \mathrm{ha}^{-1}$ in $100 \mathrm{~L}$ water in combination with various rates of the organosilicone (Table 2). Treatments were applied to the one-year-old needles of the same three clones (A, B and C) of potted Pinus radiata used in Experiment 1 and two treatments from that experiment were repeated. Treatment application and determination of phosphorous acid uptake were as described for Experiment 1.

\section{Experiment 3: Testing the efficacy of the best acid/} adjuvant combination against Phytophthora species using a detached needle bioassay

Both rates of phosphorous acid tested previously $\left(3 \mathrm{~kg} \mathrm{ha}^{-1}\right.$ and $12 \mathrm{~kg} \mathrm{ha}^{-1}$ ) were evaluated with the best-performing adjuvant $\mathrm{Du} \mathrm{Wett}^{\circ}$ added at $0.2 \%$ on the same three Pinus radiata clones (A, B and $\mathrm{C}$ ). Treatments were applied in the equivalent of $100 \mathrm{~L} \mathrm{ha}^{-1}$ using a calibrated, moving head tracksprayer (Plant Protection Chemistry NZ, Rotorua) fitted with twinjet nozzles (TJ60-8002EVS). There were a total of 27 potted plants in the trial; three for each of the two treatments (plus a control) with each clone. After treatment, the potted plants were sheltered from rain for $72 \mathrm{~h}$ after which they were placed outside and watered regularly.

Zoospore inoculum was prepared by growing isolates on carrot agar at $17^{\circ} \mathrm{C}$ for three days. Plugs of agar and mycelium were taken from the leading edge of the colonies, flooded with clarified carrot broth (Erwin \& Ribeiro 1996) and incubated for three days at $17^{\circ} \mathrm{C}$. The resulting mycelial mats were rinsed thoroughly three times with sterile deionised water, drained and flooded with sterile pond water. Pond water was collected from a local pond and used in the development of Phytophthora pluvialis and P. kernoviae cultures. These were incubated in the dark for a further three days before zoospore release was induced with 45 minute intervals at $4^{\circ} \mathrm{C}$ in the dark at room temperature $\left(21-22^{\circ} \mathrm{C}\right)$ on a light box. Zoospore concentrations were determined using a haemocytometer and standardised to $1 \times 10^{5}$ zoospores per $\mathrm{mL}$. Zoospore suspensions were used within two hours of preparation.

Five days after treatment, 30 fascicles were collected from each potted plant, including the controls. Ten fascicles each, from each potted plant. were exposed to either a suspension in pond water of $1 \times 10^{5} \mathrm{P}$. pluvialis or P. kernoviae zoospores per $\mathrm{ml}$ for $24 \mathrm{~h}$. Controls were exposed to autoclaved pond water only. Following exposure, needles were placed on trays moistened with wet paper towels and incubated in a controlled environment $\left(17^{\circ} \mathrm{C}, 65-70 \%\right.$ relative humidity, $14 \mathrm{~h}$ photoperiod) for 10 days. After this time, the needles within each fascicle were separated and lesion length was measured.

\section{Statistical analyses}

Treatments in Experiments 1 and 2 were compared by analysis of variance and least significant difference (LSD) using the statistical program Statistix 9 (Analytical Software, USA). Results from Experiment 3 (the detached needle bioassay) were analysed using the statistical programme $\mathrm{R}$ version 2.15.2 ( $\mathrm{R}$ Development Core Team, 2012). A linear mixed effects model using maximum restricted likelihood estimation (R-package nlme) was applied to test for differences in the length of needle lesions between a zero control and phosphorous acid treatments. The fixed terms of the model contained 'phosphorous acid treatment' (factor with 3 levels: 0,3 and $12 \mathrm{~kg} \mathrm{ha}^{-1}$ ) and 'Phytophthora pathogen' (factor with 3 levels: control, $P$. pluvialis and P. kernoviae) and their interaction. 'Host tree identity', 'subsample identity' within tree and 'fascicle identity' within subsample were modelled as nested random effects. Tukey contrasts (R-package multcomp) were used to compare the effects of the phosphorous acid treatment for each Phytophthora species separately.

\section{Results and discussion}

\section{Experiment 1: Effect of four adjuvants on uptake of} phosphorous acid

\section{Comparison of adjuvants}

The results of the preliminary experiment indicated that uptake of phosphorous acid into Pinus radiata needles was low and proceeded very slowly. A similar uptake of phosphorous acid was recorded at $24 \mathrm{~h}$ after treatment for the $3 \mathrm{~kg} \mathrm{ha}^{-1}$ and $12 \mathrm{~kg} \mathrm{ha}^{-1}$ phosphorous acid application rates, $6.6 \%$ and $3.9 \%$ respectively (Treatments $1 \& 2$; Table 1). Based on this preliminary experiment, it was decided to proceed with the highest rate of phosphorous acid tested in the experiment (treatments 3-8), to maximise the acid dose absorbed by the foliage. 
Addition of $0.35 \%$ pinolene as an adjuvant did not increase uptake of phosphorous acid (Treatment 3; Table 1). This was not unexpected since this type of polymer is claimed to provide increased resistance of sprays to rain wash-off and improved adhesion on difficult-towet plants, but is not known to increase pesticide uptake.

Addition of $0.05 \%$ alcohol ethoxylate (Treatment 4) was ineffective but the addition of the same adjuvant at $0.1 \%$ (Treatment 5) significantly increased uptake of phosphorous acid. There was no additional benefit from using a higher concentration of $0.2 \%$ (Treatment 6; Table 1). This class of adjuvant is known to improve the adhesion and spreading properties of sprays, and has been shown to promote increased uptake of a range of compounds on a variety of species (Stock et al. 1992). These authors also showed that the magnitude of increased penetration varied according to properties of both the compound and the adjuvant and was influenced by surfactant concentration and target plant species.

The two organosilicone adjuvants (Du-Wett ${ }^{\odot}$ and Du-Wett ${ }^{\circ}$ Stainless) were used at the same rate $(0.2 \%)$ (Treatments $7 \& 8$ ) and both significantly increased uptake relative to the other adjuvants tested. The organosilicone blend (superspreader adjuvant (Du-Wett $\left.{ }^{\oplus}\right)$; Treatment 8) was the most effective of all the treatments tested, increasing uptake to nine fold greater than that of the phosphorous acid used alone (Table 1). This organosilicone blend was used at a higher rate of addition than when typically used as a superspreader in horticultural operations $(\leq 0.1 \%)$ in order to maximise its penetration properties.

The pH-stable organosilicone penetrant (Du Wett ${ }^{\oplus}$ Stainless) was included in the study because it is recommended for use with acidic active ingredients (AgriMedia Ltd 2013; Policello and Gaskin 2010) such as phosphorous acid. However, the formulated phosphorous acid used in this study, Agrifos ${ }^{\oplus} 600$, is buffered to moderately neutral ( $\mathrm{pH}$ of 6.8) meaning use of a $\mathrm{pH}$-stable organosilicone penetrant is not essential. This was useful since the $\mathrm{pH}$ stable organosilicone penetrant was more expensive than the organosilicone blend.

Standard organosilicone superspreader adjuvants should only be used at neutral $\mathrm{pH}(6-8)$ as these adjuvants degrade rapidly in acid/alkaline environments (Policello et al. 1995). The superspreader adjuvant used in the current trial is disclosed as a proprietary blend of organosilicone and organic fluids and is not typically used as a penetrant. However, it contains polymers with uptakeenhancing capability when combined, at appropriate concentrations, with phosphorous acid.

\section{Droplet spread}

The spread of droplets on a leaf surface is a measure of how well a spray can be expected to cover the plant surface following droplet adhesion. Pinus radiata foliage is classified as easy-to-wet, with a surface contact angle of $64^{\circ}$ (Gaskin et al. 2005). Surfactants are most useful for improving droplet spread and adhesion on difficultto-wet species (Gaskin et al. 2005). The effect of adjuvants on droplet spread on easy-to-wet foliage confirmed this (Table 1). Although significant, pinolene increased the spread of phosphorous acid spray droplets negligibly. Alcohol ethoxylate improved droplet spread and the effect increased with increasing concentration (Table 1). The pH-stable organosilicone provided slightly enhanced droplet spreading relative to either pinolene or alcohol ethoxylate. The most effective treatment, however, was the organosilicone blend superspreader, which significantly increased coverage of needle surfaces by almost three-fold compared to the controls.

\section{Experiment 2: Optimising uptake of phosphorous acid}

A repeat of the control phosphorous acid treatment at a rate of $12 \mathrm{~kg} \mathrm{ha}^{-1}$ confirmed that very little penetration of phosphorous acid occurred in the absence of adjuvant (Treatment 2R; Table 2). A repeat of Treatment 8 from Experiment 1 (8R, Table 2) confirmed that the organosilicone blend increased phosphorous acid uptake. This treatment and all the others using the organosilicone blend superspreader (Treatments 9-12) increased uptake by more than nine-fold relative to the control (Table 2). The highest uptake occurred at the highest concentration tested $(0.2 \%)$ at both $24 \mathrm{~h}$ and $72 \mathrm{~h}$ after treatment.

Uptake with the lowest concentration of organosilicone blend $(0.05 \%)$ showed high variability within replicates and, as a result, this treatment was repeated with similar variability in results. The reasons for this are not obvious, but suggest that a low concentration of organosilicone blend adjuvant will provide highly variable uptake of phosphorous acid into Pinus radiata foliage.

An analysis of treatments 8R, 10, 11 \& 12 (Table 2) as a factorial of adjuvant concentration $(0.1 \%$ and $0.2 \%)$ and harvest time ( $24 \mathrm{~h}$ and $72 \mathrm{~h}$ ) showed that the main effects of both concentration and uptake over time were significant $(p<0.05)$. Thus, uptake of phosphorous acid is expected to be greater with the higher concentration of organosilicone blend and to proceed for up to 72 HAT at least (Table 2). Droplets of all treatments were still visibly hydrated on foliage at $24 \mathrm{HAT}$, whereas at 72 HAT all droplets had visibly dried. Uptake is likely to cease when fungicide deposits become dry (Merritt 1982) so the rate of uptake will slow with time.

\section{Testing the efficacy of best acid/adjuvant combination} against Phytophthora species

Lesion length of Pinus radiata needles inoculated with either Phytophthora kernoviae or P. pluvialis was 


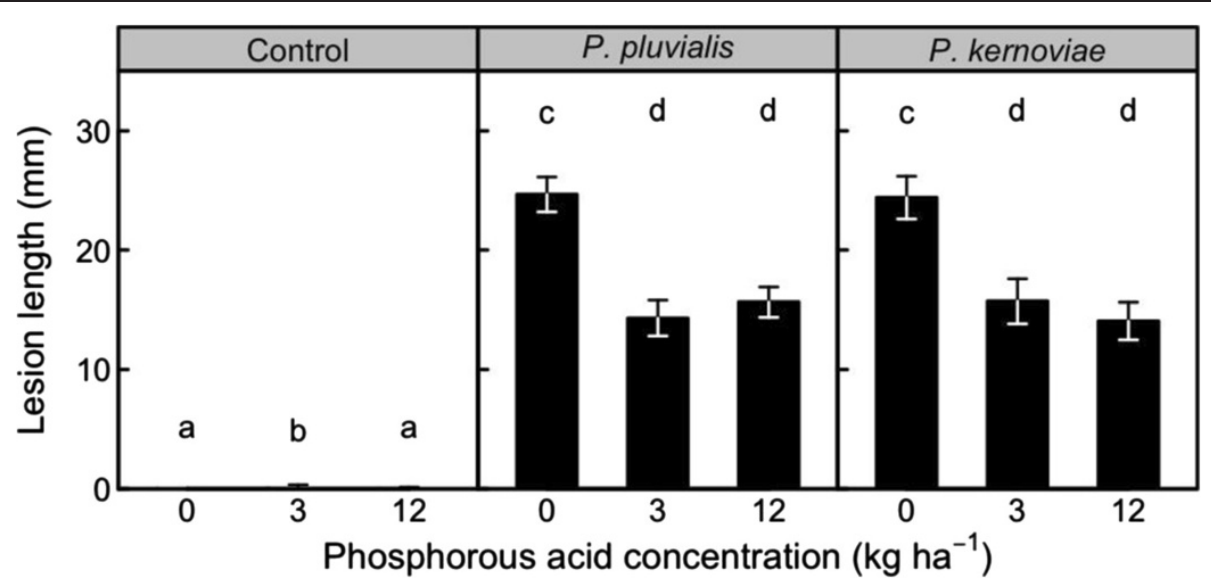

Figure 1 Lesion length (model predictions and confidence intervals) on Pinus radiata needles exposed to Phytophthora pluvialis or Phytophthora kernoviae for 24 hours following treatment with either $3 \mathrm{~kg} \mathrm{ha}^{-1}$ or $12 \mathrm{~kg} \mathrm{ha}^{-1}$ phosphorous acid each applied in $100 \mathrm{~L}$ water containing $0.2 \%$ organosilicone-blend superspreader adjuvant (Du-Wett $\left.{ }^{\oplus}\right)$.

significantly reduced by application of the phosphorous acid treatments containing $0.2 \%$ organosilicone blend adjuvant at both application rates tested compared to controls (Figure 1). However, there was no significant difference in lesion length between the low- and highdose treatments used and either Phytophthora species tested. This result indicated that sufficient phosphorous acid had been absorbed by the needles to affect pathogen activity at both concentrations. In addition, these results indicate that phosphorous acid has activity against the target Phytophthora species when it is applied with organosilicone blend adjuvant. Similar bioassays have been used extensively to demonstrate the efficacy of phosphorous acid application to imply field based control for a range of Phytophthora diseases (Barrett et al. 2003; Garbelotto and Schmidt 2009; Shearer et al. 2012). While bioassays can provide a useful indication of treatment efficacy, in some cases, they have also been shown to differ significantly from field based analyses and are therefore no substitute for field based results (Shearer et al. 2012). Therefore, field trials involving application of phosphorous acid to mature Pinus radiata trees need to be carried out to determine an optimum dose for management of needle diseases in the field.

Kanaskie et al. (2011) conducted field trials to test the efficacy of phosphorous acid for the control of sudden oak death in south western Oregon tanoak. In aerial spray trials phosphorous acid was applied at two rates, $17.36 \mathrm{~kg} \mathrm{ha}^{-1}$ and $34.72 \mathrm{~kg} \mathrm{ha}^{-1}$, in conjunction with Pentra-bark ${ }^{\odot}$ in $160 \mathrm{~L}$ water $\mathrm{ha}^{-1}$. Detached-twig and log bioassays with P. ramorum, as well as in situ stem inoculations with Phytophthora gonapodyides (Petersen) Buisman, were carried out to investigate treatment efficacy. Aerial spray with phosphorous acid at both application rates consistently resulted in smaller bole lesions on trees challenge inoculated with $P$. gonapodyides in situ and logs inoculated with $P$. ramorum. However, results from detached canopy twig assays were variable and showed only small treatment effects. These findings demonstrate the potential variability of field based treatments and the need to assess treatment effects both infield and using bio-assays tested across different tissues. In the present study, bioassays focussed on detached needle inoculations as red needle cast has, as yet, only been shown to affect Pinus radiata needles (Dick et al. 2013). Further confirmation of these results in the field is essential to establish the efficacy of broad-scale treatment for the control of red needle cast in Pinus radiata.

\section{Conclusions}

There was very little penetration of phosphorous acid into the foliage of Pinus radiata 24 hours after treatment in the absence of adjuvants. The addition of either an alcohol ethoxylate or organosilicone adjuvant improved uptake. The highest uptake of phosphorous acid occurred with an organosilicone blend adjuvant (DuWett ${ }^{\oplus}$ ) at a concentration of $0.2 \%$, and uptake progressed over a period of more than 24 hours after treatment. The addition of either of these adjuvants improved surface coverage of phosphorous acid sprays and they are also likely to have some beneficial effects on spray retention.

It is clear that the use of an organosilicone blend adjuvant in phosphorous acid treatments will improve coverage of sprays on Pinus radiata, in addition to its effects on the penetration of phosphorous acid into the plants. Its use is recommended to increase the uptake of phosphorous acid when applied to Pinus radiata for management of red needle-cast disease. Preliminary indications 
from the detached needle bioassays indicate that the rates of phosphorous acid used in this investigation ( $3 \mathrm{~kg} \mathrm{ha}^{-1}$ and $12 \mathrm{~kg} \mathrm{ha}^{-1}$ ) have the potential to reduce infection of Pinus radiata by Phytophthora species including P. kernoviae and P. pluvialis. Field trials are needed to confirm this.

\section{Competing interests}

The authors declare that they have no competing interests.

\section{Authors' contributions}

$C R$ and $R G$ lead the conceptual development of this paper. RG and DH carried out all experimental work to characterise the penetration of phosphite as affected by four commercially available adjuvants. CR designed the study to test the best performing treatment on potted $P$. radiata, with NW the conceptual lead on work associated with in-vitro testing of P. kernoviae and P. pluvilais. MB analysed data and developed models to present Figure 1. All authors read and approved the final manuscript.

\section{Acknowledgements}

The Forest Owners Association, New Zealand, and Ministry of Business Innovation and Employment, New Zealand, provided the funding for this work.

\section{Author details}

'Scion, 49 Sala Street, Fenton Park, Private Bag 3020, Rotorua 3046, New Zealand. ²Plant Protection Chemistry NZ, PO Box 6282, 49 Sala Street, Fenton Park, Rotorua 3043, New Zealand.

Received: 11 April 2013 Accepted: 5 February 2014

Published online: 24 May 2014

\section{References}

AgriMedia Ltd. (2013). New Zealand Novachem Agrichemical Manual (pp. 365-366). New Zealand: Ashcroft House, Christchurch.

Barrett, S, Shearer, B, \& Hardy, GESJ. (2003). The efficacy of phosphite applied after inoculation on the colonisation of Banksia brownii sterns by Phytophthora cinnamomi. Australasian Plant Pathology, 32, 1-7.

Cohen, Y, \& Coffey, MD. (1986). Systemic fungicides and the control of oomycetes. Annual Review Phytopathology, 24, 311-388.

Dick, M, Williams, NM, Hood, IA, Bader, M. (2014). Pathogenicity of Phytophthora pluvialis to Pinus radiata and its relation with red needle cast disease in New Zealand. New Zealand Journal of Forestry Science. 44, 6 .

Erwin, DC, \& Ribeiro, O. (1996). Phytophthora Diseases Worldwide. Minnesota: APS Press.

Garbelotto, M, \& Schmidt, DJ. (2009). Phosphonate controls sudden oak death pathogen for up to two years. California Agriculture, 63, 10-17.

Gaskin, RE, Steele, KD, \& Forster, WD. (2005). Characterising plant surfaces for spray adhesion and retention. New Zealand Plant Protection, 58, 197-183.

Gaskin, RE, Logan, DP, May, W, Rowe, CA, Steele, KD, van Leeuwen, RM, \& Connolly, PG. (2012). Control of passionvine hopper and cicada eggs on kiwifruit canes with bifenthrin and a new super-penetrant adjuvant. New Zealand Plant Protection, 65, 100-105.

Graham, JH. (2011). Phosphite for control of Phytophthora diseases in citrus: model for management of Phytophthora species on forest trees? New Zealand Journal Forestry Science, 41S, S49-S56.

Hardy, GESJ, Barrett, S, \& Shearer, BL. (2001). The future of phosphite as a fungicide to control the soilborne plant pathogen Phytophthora cinnamomi in natural ecosystems. Australasian Plant Pathology, 30, 133-139.

Kanaskie, A, Hansen, EM, Sutton, W, Reeser, P, \& Choquette, C. (2011). Application of phosphonate to prevent sudden oak death in south-western Oregon tanoak (Notholithocarpus densiflorus) forests. New Zealand Journal of Forestry Science, 41S, S177-S187.

Lobato, MC, Machinandiarena, MF, Tambascio, C, Dosio, GAA, Caldiz, DO, Daleo, GR, Andreu, AB, \& Olivieri, FP. (2011). Effect of foliar applications of phosphite on post-harvest potato tubers. European Journal of Plant Pathology, $130,155-163$.

Merritt, CR. (1982). The influence of form of deposit on the phytotoxicty of MCPA, paraquat and glyphosate applied as individual drops. Annals of Applied Biology, 101, 527-532.
Policello, GA, \& Gaskin, RE. (2010). Hydrolysis resistant organosilicon adjuvant for glyphosate. In P Baur \& M Bonnet (Eds.), Proceedings of the 9th International Symposium on Adjuvants for Agrochemicals Techinical University of Munich. Germany: Freising.

Policello, GA, Stevens, PJG, Forster, WA, \& Murphy, GJ. (1995). The influence of pH on the performance of organosilicone surfactants. In FR Hall, PD Berger \& HM Collins (Eds.), Pesticide Formulations and Application Systems: 14th Volume (pp. 313-317). West Conshohocken, PA, USA: ASTM.

Rebollar-Alviter, A, Madden, LV, \& Ellis, MA. (2007). Pre- and post-infection activity of azoxystrobin, pyraclostrobin, mefenoxam, and phosphite against leather rot of strawberry, caused by Phytophthora cactorum. Plant Disease, 91, 559-564.

Reeser, PW, Sutton, W, Hansen, EM. (2013). Phytophthora pluvialis, a new species found in mixed tanoak - Douglas-fir forests of western Oregon, U.S.A. North American Fungi 8(7), 1-8.

Reglinski, T, Spiers, TM, Dick, MA, Taylor, JT, \& Gardner, J. (2009). Management of phytophthora root rot in radiata pine seedlings. Plant Pathology, 58, 723-730.

Shearer, BL, \& Crane, CE. (2009). Influence of site and rate of low-volume aerial phosphite spray on lesion development of Phytophthora cinnamomi and phosphite persistence in Lambertia inermis var. inermis and Banksia grandis. Australasian Plant Pathology, 38, 288-304.

Shearer, BL, Crane, CE, Scott, PM, \& Hardy, GES. (2012). Variation between plant species of in-planta concentration and effectiveness of low-volume phosphite spray on Phytophthora cinnamomi lesion development. Australasian Plant Pathology, 41, 505-517.

Stock, D, Edgerton, BM, Gaskin, RE, \& Holloway, PJ. (1992). Surfactant-enhanced foliar uptake of some organic compounds: Interactions with two model polyoxyethylene aliphatic alcohols. Pesticide Science, 34, 233-242.

Tomlin, C. (2006). The Pesticide Manual (Fourteenth ed.). Hampshire: British Crop Protection Council.

Tynan, KM, Wilkinson, CJ, Holmes, JM, Dell, B, Colquhoun, IJ, McComb, JA, \& Hardy, GEJ. (2001). The long-term ability of phosphite to control Phytophthora cinnamomi in two native plant communities of Western Australia. Australian Journal of Botany, 49, 761-770.

Zabkiewicz, JA. (2000). Adjuvants and herbicidal efficacy - Present status and future prospects. Weed Research, 40, 139-149.

\section{doi:10.1186/s40490-014-0008-5}

Cite this article as: Rolando et al:: The use of adjuvants to improve uptake of phosphorous acid applied to Pinus radiata needles for control of foliar Phytophthora diseases. New Zealand Journal of Forestry Science 2014 44:8.

\section{Submit your manuscript to a SpringerOpen ${ }^{\odot}$ journal and benefit from:}

- Convenient online submission

Rigorous peer review

- Immediate publication on acceptance

- Open access: articles freely available online

- High visibility within the field

- Retaining the copyright to your article

Submit your next manuscript at $>$ springeropen.com 